\title{
Tillage, Crop Rotation, and Cultural Practice Effects on Dryland Soil Carbon Fractions
}

\author{
Upendra M. Sainju $^{1 *}$, Andrew W. Lenssen ${ }^{2}$, Thecan Caesar-TonThat ${ }^{1}$, Jalal D. Jabro ${ }^{1}$, \\ Robert T. Lartey ${ }^{1}$, Robert G. Evans ${ }^{1}$, Brett L. Allen ${ }^{1}$ \\ ${ }^{1}$ US Department of Agriculture, Agricultural Research Service, Northern Plains Agricultural Research Laboratory, Sidney, USA; \\ ${ }^{2}$ Agronomy Department, Iowa State University, Ames, USA. \\ Email: *upendra.sainju@ars.usda.gov
}

Received June $5^{\text {th }}, 2012$; revised July $9^{\text {th }}, 2012$; accepted July $22^{\text {nd }}, 2012$

\begin{abstract}
Information is needed on novel management practices to increase dryland $\mathrm{C}$ sequestration and soil quality in the northern Great Plains, USA. We evaluated the effects of tillage, crop rotation, and cultural practice on dryland crop biomass (stems and leaves) yield, surface residue, and soil C fractions at the $0-20 \mathrm{~cm}$ depth from 2004 to 2008 in a Williams loam in eastern Montana, USA. Treatments were two tillage systems (no-tillage [NT] and conventional tillage [CT]), two crop rotations (continuous spring wheat [Triticum aestivum L.] [CW] and spring wheat-barley [Hordeum vulgaris L.] hay-corn [Zea mays L.]-pea [Pisum sativum L.] [W-B-C-P]), and two cultural practices (regular [conventional seed rates and plant spacing, conventional planting date, broadcast $\mathrm{N}$ fertilization, and reduced stubble height] and ecological [variable seed rates and plant spacing, delayed planting, banded $\mathrm{N}$ fertilization, and increased stubble height]). Carbon fractions were soil organic $\mathrm{C}$ (SOC), particulate organic $\mathrm{C}$ (POC), microbial biomass $\mathrm{C}$ (MBC), and potential C mineralization (PCM). Crop biomass was $24 \%$ to $39 \%$ greater in W-B-C-P than in CW in 2004 and 2005. Surface residue C was $36 \%$ greater in NT than in CT in the regular practice. At $5-20 \mathrm{~cm}$, SOC was $14 \%$ greater in NT with W-B-C-P and the regular practice than in CT with $\mathrm{CW}$ and the ecological practice. In $2007, \mathrm{POC}$ and PCM at $0-20 \mathrm{~cm}$ were $23 \%$ to $54 \%$ greater in NT with $\mathrm{CW}$ or the regular practice than in CT with $\mathrm{CW}$ or the ecological practice. Similarly, MBC at $10-20 \mathrm{~cm}$ was $70 \%$ greater with the regular than with the ecological practice in NT with CW. Surface residue, PCM, and MBC declined from autumn 2007 to spring 2008. No-tillage with the regular cultural practice increased surface residue and soil $\mathrm{C}$ storage and microbial biomass and activity compared to conventional tillage with the ecological practice. Mineralization reduced surface residue and soil labile $\mathrm{C}$ fractions from autumn to spring.
\end{abstract}

Keywords: Carbon Sequestration; Dryland Soil; Labile Carbon; Management Practices; Residue Carbon

\section{Introduction}

Sequestering atmospheric $\mathrm{CO}_{2}$ through plant photosynthesis in the soil as organic matter is getting increased attention, because reduction in $\mathrm{CO}_{2}$ concentration can reduce global warming $[1,2]$. In croplands, $\mathrm{C}$ sequestration occurs when non-harvested crop residues, such as stems, leaves, and roots, are returned to the soil, followed by their placement at the soil surface using NT that reduces the mineralization of residue and SOC [3-5]. Carbon sequestration rates, however, depend on the balance between the amounts of plant residue $\mathrm{C}$ input and the rate of $\mathrm{C}$ mineralized in unmanured soil $[6,7]$. Other benefits of increasing $\mathrm{C}$ storage include enhancement of soil structure and soil water-nutrient-crop productivity relationships [8].

Incentives by governments and private companies for

*Corresponding author. the compensation of $\mathrm{C}$ credit in agricultural soils have led to increased need for $\mathrm{C}$ sequestration and storage using novel management practices. Some of these practices are NT management, diversified crop rotations, and improved cultural practices. Studies have shown that NT with continuous cropping can increase dryland soil C storage compared to CT with crop-fallow [3-5]. In the northern Great Plains, NT with continuous cropping system can increase $\mathrm{C}$ sequestration by as much as $233 \mathrm{~kg} \mathrm{C}$ $\mathrm{ha}^{-1} \cdot \mathrm{yr}^{-1}$ compared to a loss of $141 \mathrm{~kg} \cdot \mathrm{C} \cdot \mathrm{ha}^{-1} \cdot \mathrm{yr}^{-1}$ in CT with crop-fallow [9]. Sherrod et al. [4] found that increased cropping intensity in NT increased dryland SOC in the central Great Plains after 12 yr. Conversion from CT to NT can sequester C at $570 \pm 140 \mathrm{~kg} \cdot \mathrm{C} \cdot \mathrm{ha}^{-1} \cdot \mathrm{yr}^{-1}$, reaching equilibrium in 15 to $20 \mathrm{yr}$ and enhanced crop rotation can sequester at $200 \pm 120 \mathrm{~kg} \cdot \mathrm{C} \cdot \mathrm{ha}^{-1} \cdot \mathrm{yr}^{-1}$, reaching equilibrium in 40 to $60 \mathrm{yr}$ [10]. The NT management can also increase annual crop yields due to efficient wa- 
ter use as a result of increased soil water conservation from residue accumulation at the soil surface compared to $\mathrm{CT}[11,12]$.

Continuous cropping of diversified crops in the rotation can efficiently utilize water and nutrients and sustain yields compared to monocropping in water-limited dryland farming systems [13,14]. One such crop is pea, which uses less soil water than spring wheat and barley, thereby resulting in more water available for succeeding crops and increasing their yields $[11,14]$. Pea, being a legume, also fixes $\mathrm{N}$ from the atmosphere and has higher $\mathrm{N}$ concentration than spring wheat or barley $[12,15]$. Because of greater $\mathrm{N}$ supply, $\mathrm{N}$ fertilization rates to crops following pea can be reduced $[12,14]$. Other benefits of crop diversification include effective control of weeds, diseases, and pests $[13,14]$, reductions in the risk of crop failure, farm inputs, and duration of fallow, and improvement in economic and environmental sustainability [16,17].

Increased $\mathrm{C}$ storage can also improve biological soil quality as indicated by enhanced microbial biomass and activity $[5,18,19]$. These can be estimated by measuring labile $\mathrm{C}$ fractions, such as MBC and PCM [20,21]. The $\mathrm{MBC}$ refers to $\mathrm{C}$ storage in the body of microorganisms and also known as microbial biomass. Similarly, PCM refers to soil $\mathrm{C}$ mineralization and is related to microbial activity. Because of a large pool size and inherent spatial variability, SOC changes slowly with management practices [18]. As a result, measurement of SOC alone does not adequately reflect changes in soil quality and nutrient status [18,19]. Active C fractions, such as MBC and PCM that change rapidly with time due to management practices, can better reflect changes in soil quality and productivity that alter nutrient dynamics due to immobilization-mineralization [20,21]. Similarly, POC that contains coarse organic matter, has been considered as an intermediate fraction of SOC between active and slow fractions that changes rapidly due to management practices [22]. The POC also provides substrates for microorganisms and influences soil aggregation [23].

In the northern Great Plains, traditional farming systems, such as CT with wheat-fallow, for the last 50 to $100 \mathrm{yr}$ have decreased SOC levels by $30 \%$ to $50 \%[7,24]$. Both tillage and fallowing reduce SOC by increasing soil organic matter mineralization $[25,26]$ and reducing the amount of plant residue returned to the soil [10,27]. As a result, traditional farming systems have become unsustainable and uneconomical [16]. Controlling weeds in NT cropping systems is also a major concern in dryland farming systems. Some of the cultural practices used for weed control include high crop seeding rates, banded fertilization, delayed planting and harvest, and increased retention of crop residue [28,29]. Although information is available about the use of NT with continuous cropping in increasing soil $\mathrm{C}$ storage compared to CT with crop-fallow, little is known about the combined effects of tillage, diversified crop rotation, and cultural practice on dryland surface residue and soil $\mathrm{C}$ fractions.

Because of the short growing season due to cold weather and lack of enough time for sampling before crop planting in the spring, soil samples are normally taken after harvest in the autumn for testing nutrient levels and recommending fertilizer rates for succeeding crops in the next year in the northern Great Plains [16,30]. As a result, fertilizers are applied in the autumn instead of spring in the succeeding year. This results in substantial loss of nutrients, especially $\mathrm{N}$ and $\mathrm{P}$, from fertilizers due to leaching, surface runoff, volatilization, and denitrification. To reduce this loss, it is recommended that soil tests be done and fertilizers applied before planting in the spring [30]. Since C mineralization can continue during the winter, it could be possible that $C$ levels vary in surface residue and soil samples collected in the autumn and spring. We hypothesized that NT with diversified crop rotation and the ecological cultural practice would increase surface residue and soil $\mathrm{C}$ fractions compared to CT with monocropping and the regular cultural practice, and that surface residue and labile $\mathrm{C}$ fractions would decline more than SOC from the autumn to the succeeding spring due to mineralization and lack of additional inputs, regardless of management practices. Our objectives were to: 1) determine the amount of dryland crop biomass (stems and leaves) returned to the soil as influenced by tillage, crop rotation, and cultural practice from 2004 to 2007 in eastern Montana, 2) quantify their effects on surface residue and soil $\mathrm{C}$ fractions (SOC, POC, PCM, and $\mathrm{MBC}$ ) at $0-20 \mathrm{~cm}$, and 3) examine changes in surface residue and soil $\mathrm{C}$ fractions as influenced by management practices from autumn 2007 to spring 2008.

\section{Materials and Methods}

\subsection{Experimental Site and Treatments}

From 2004 to 2008, the experiment was carried out on a dryland farm site, $8 \mathrm{~km}$ northwest of Sidney $\left(47^{\circ} 46^{\prime} \mathrm{N}\right.$, $104^{\circ} 16^{\prime} \mathrm{W}$; elevation $\left.690 \mathrm{~m}\right)$, Montana, USA. The climate is semiarid, with mean monthly air temperature ranging from $-8^{\circ} \mathrm{C}$ in January to $23^{\circ} \mathrm{C}$ in July and August, and mean annual precipitation (68-yr average) of 357 $\mathrm{mm}, 80 \%$ of which occurs during the crop growing season (April-November). The soil is a Williams loam (fineloamy, mixed, superactive, frigid, Typic Argiustolls) with $350 \mathrm{~g} \cdot \mathrm{kg}^{-1}$ sand, $325 \mathrm{~g} \cdot \mathrm{kg}^{-1}$ silt, $325 \mathrm{~g} \cdot \mathrm{kg}^{-1}$ clay, and $6.1 \mathrm{pH}$ at the $0-20 \mathrm{~cm}$ depth. The SOC contents at 0 - 5 and $5-20 \mathrm{~cm}$ prior to the initiation of the experiment in April 2004 were 8.8 and $21.7 \mathrm{Mg} \cdot \mathrm{C} \cdot \mathrm{ha}^{-1}$, respectively. Previous cropping system for the last $10 \mathrm{yr}$ was CT with spring wheat-fallow.

Treatments included two tillage practices (NT and CT), 
two crop rotations (continuous spring wheat $[\mathrm{CW}]$ and spring wheat-barley hay-corn-pea [W-B-C-P]), and two cultural practices (regular and ecological). The cultural practices used for crops in the rotation are described in Table 1. The NT plots were left undisturbed, except for applying fertilizer and planting crops in rows. The CT plots were tilled one to two times a year with a field cultivator to a depth of $7-8 \mathrm{~cm}$ for seedbed preparation and weed control. In the four-year crop rotation in W-B-C-P, each phase (spring wheat, hay barley, corn, and pea) of the crop rotation was present in every year. Treatments were arranged in a split-plot design in randomized complete block with three replications. Tillage was considered as the main-plot and the factorial combination of crop rotation and cultural practice as the split-plot treatment. The split plot size was $12.2 \mathrm{~m} \times 12.2 \mathrm{~m}$.

\subsection{Crop Management}

At planting in April, 2004 to 2007, P fertilizer as monoammonium phosphate $(11 \% \mathrm{~N}, 23 \% \mathrm{P})$ at $56 \mathrm{~kg} \cdot \mathrm{P} \cdot \mathrm{ha}^{-1}$ and $\mathrm{K}$ fertilizer as muriate of potash $(60 \% \mathrm{~K})$ at 48 $\mathrm{kg} \cdot \mathrm{K} \cdot \mathrm{ha}^{-1}$ were banded to a depth of $5 \mathrm{~cm}$ to all crops. Nitrogen fertilizer as urea $(46 \% \mathrm{~N})$ (either broadcast or banded [Table 1]) and monoammonium phosphate (banded) was applied at $101 \mathrm{~kg} \cdot \mathrm{N} \cdot \mathrm{ha}^{-1}$ for spring wheat, $67 \mathrm{~kg} \cdot \mathrm{N} \cdot \mathrm{ha}^{-1}$ for barley hay, and $78 \mathrm{~kg} \cdot \mathrm{N} \cdot \mathrm{ha}^{-1}$ for corn. Pea received $6 \mathrm{~kg} \cdot \mathrm{N} \cdot \mathrm{ha}^{-1}$ from monoammonium phosphate. Nitrogen fertilization rate to each crop was adjusted for soil $\mathrm{NO}_{3}-\mathrm{N}$ content to a depth of $60 \mathrm{~cm}$ measured after harvest of previous crop in the autumn. Spring wheat (cv. Reeder) was planted from early April to mid-May and pea (cv. Majoret) and barley hay (cv. Haybet) from early to mid-April (Table 1) with a no-till drill at a spacing of $20.3 \mathrm{~cm}$. Corn (cv. 39T67-RR) was planted in early May at a spacing of $76 \mathrm{~cm}$ in 2004 and $61 \mathrm{~cm}$ from 2005 to 2007. The narrow spacing for corn from 2005 to 2007 compared to 2004 was adapted to use soil water more efficiently and increase grain yield. Growing season weeds were controlled with selective post-emergence herbicides appropriate for each crop.
Contact herbicides were applied at preplanting and postharvest. In late June or early July, aboveground biomass of barley was harvested for hay with a self-propelled mower-conditioner and round baler after determining dry yield from two $0.5 \mathrm{~m}^{2}$ plots at $60^{\circ} \mathrm{C}$ for $3 \mathrm{~d}$. In August, total aboveground biomass (stems, leaves, and grains) yield of spring wheat and pea was determined from two $0.5 \mathrm{~m}^{2}$ areas outside yield rows after determining dry yields as above. At the same time, grain yield (ovendried basis at $60^{\circ} \mathrm{C}$ ) was determined by harvesting grains from a swath of $1.5 \mathrm{~m} \times 12.0 \mathrm{~m}$ using a combine harvester. In October, corn biomass and grain yields were determined from areas as described above. Biomass (stems and leaves) yield of spring wheat, pea, and corn was determined by deducting grain yield from total aboveground biomass. During harvest, grains were removed but biomass of spring wheat, pea, and corn were returned to the soil.

\subsection{Surface Residue and Soil Sample Collection and Analysis}

In November 2007, a month after crop harvest, soil surface residue samples were collected from five $30 \mathrm{~cm} \times$ $30 \mathrm{~cm}$ areas randomly in the central rows of the plot, composited, washed with water to remove soil, and dried in the oven at $60^{\circ} \mathrm{C}$ for $7 \mathrm{~d}$ to obtain dry matter weight. Samples were ground to pass a $1 \mathrm{~mm}$ screen to determine $\mathrm{C}$ concentration. After removing the residue, soil samples were collected with a hand probe $(5 \mathrm{~cm}$ inside diameter) from the $0-20 \mathrm{~cm}$ depth from five places in the central rows of the plot. These were separated into $0-5,5-10$, and $10-20 \mathrm{~cm}$ depth increments, composited within a depth, air-dried, ground, and sieved to $2 \mathrm{~mm}$ for determining $\mathrm{C}$ fractions. The process was repeated again in April 2008 by collecting surface residue and soil samples and preparing exactly as above for $\mathrm{C}$ analysis. Because of the difficulty in getting intact soil cores due to low water content, only one additional core $(5 \mathrm{~cm}$ inside diameter) containing undisturbed sample was collected from each depth in 2007 and 2008 to determine bulk

Table 1. Description of cultural practices (regular and ecological) used for crops in the rotation.

\begin{tabular}{|c|c|c|c|c|c|}
\hline Crop & Cultural practice & Seeding rate (million seeds $\mathrm{ha}^{-1}$ ) & $\mathrm{N}$ fertilization at planting & Planting date & Stubble height $(\mathrm{cm})$ \\
\hline \multirow[t]{2}{*}{ Spring wheat } & Regular & 2.23 & Broadcast & Early to mid April & 20 \\
\hline & Ecological & 2.98 & Banded & Early to mid May & 30 \\
\hline \multirow[t]{2}{*}{ Pea } & Regular & 0.60 & Broadcast & Early to mid April & 5 \\
\hline & Ecological & 0.92 & Banded & Early to mid April & 5 \\
\hline \multirow[t]{2}{*}{ Barley hay } & Regular & 2.23 & Broadcast & Early to mid April & 5 \\
\hline & Ecological & 2.98 & Banded & Early to mid April & 5 \\
\hline \multirow[t]{2}{*}{ Corn } & Regular & 0.04 & Broadcast & Early May & 5 \\
\hline & Ecological & 0.05 & Broadcast & Early May & 5 \\
\hline
\end{tabular}


density by dividing the mass of the oven-dried $\left(105^{\circ} \mathrm{C}\right)$ soil by the volume of the core. Soil bulk density was not different among treatments and sampling dates averaged 1.34, 1.36, and $1.49 \mathrm{Mg} \cdot \mathrm{m}^{-3}$ at $0-5,5-10$, and $10-20$ $\mathrm{cm}$, respectively.

Total $\mathrm{C}$ concentration $\left(\mathrm{g} \cdot \mathrm{C} \cdot \mathrm{kg}^{-1}\right)$ in the surface residue was determined by using a dry combustion $\mathrm{C}$ and $\mathrm{N}$ analyzer (LECO Corp., St Joseph, MI). Carbon content $\left(\mathrm{Mg} \cdot \mathrm{C} \cdot \mathrm{ha}^{-1}\right)$ in the residue was determined by multiplying dry matter weight by $\mathrm{C}$ concentration. The SOC concentration in soil samples was determined by using the $\mathrm{C}$ and $\mathrm{N}$ analyzer as above after grinding the samples to $<0.5 \mathrm{~mm}$ and pretreating the soil with $5 \% \mathrm{H}_{2} \mathrm{SO}_{3}$ to remove inorganic $\mathrm{C}$ [31]. For determining POC, $10 \mathrm{~g}$ soil sample was dispersed with $30 \mathrm{~mL}$ of $5 \mathrm{~g} \cdot \mathrm{L}^{-1}$ sodium hexametaphosphate by shaking for $16 \mathrm{~h}$ and the solution was poured through a $0.053 \mathrm{~mm}$ sieve [22]. The solution and particles that passed through the sieve and contained mineral associated and water soluble $\mathrm{C}$ were dried at $50^{\circ} \mathrm{C}$ for 3 to $4 \mathrm{~d}$ and SOC concentration was determined by using the analyzer as above after pretreating with $5 \%$ $\mathrm{H}_{2} \mathrm{SO}_{3}$. The POC concentration was determined by the difference between SOC in the whole-soil and that in the particles that passed through the sieve after correcting for the sand content.

The PCM in air-dried soils was determined by the method modified by Haney et al. [32]. Ten grams of soil sample was moistened with water at $50 \%$ field capacity $\left(0.25 \mathrm{~m}^{3} \cdot \mathrm{m}^{-3}\right.$ [33]) and placed in a $1 \mathrm{~L}$ jar containing beakers with $2 \mathrm{~mL}$ of $0.5 \mathrm{M} \mathrm{NaOH}$ to trap evolved $\mathrm{CO}_{2}$ and $20 \mathrm{~mL}$ of water to maintain high humidity. Soils were incubated in the jar at $21^{\circ} \mathrm{C}$ for $10 \mathrm{~d}$. At $10 \mathrm{~d}$, the beaker containing $\mathrm{NaOH}$ was removed from the jar and PCM concentration was determined by measuring $\mathrm{CO}_{2}$ absorbed in $\mathrm{NaOH}$, which was back-titrated with $1.5 \mathrm{M}$ $\mathrm{BaCl}_{2}$ and $0.1 \mathrm{M} \mathrm{HCl}$. The moist soil used for determining PCM was subsequently used for determining MBC by the modified fumigation-incubation method for air-dried soils [34]. This container was incubated twice because $\mathrm{MBC}$ determination required moist-soil. The method also required mineralizable $\mathrm{C}$ to be flushed out during the first incubation [34]. The moist soil was fumigated with ethanol-free chloroform for $24 \mathrm{~h}$ and placed in a $1 \mathrm{~L}$ jar containing beakers with $2 \mathrm{~mL}$ of $0.5 \mathrm{M}$ $\mathrm{NaOH}$ and $20 \mathrm{~mL}$ water. As with PCM, fumigated moist soil was incubated for $10 \mathrm{~d}$ and $\mathrm{CO}_{2}$ absorbed in $\mathrm{NaOH}$ was back-titrated with $\mathrm{BaCl}_{2}$ and $\mathrm{HCl}$. The $\mathrm{MBC}$ concentration was calculated by dividing the amount of $\mathrm{CO}_{2}-\mathrm{C}$ absorbed in $\mathrm{NaOH}$ by a factor of 0.41 [35] without subtracting the values from the non-fumigated control [34].

The SOC, POC, PCM, and MBC contents (Mg or $\mathrm{kg} \cdot \mathrm{C} \cdot \mathrm{ha}^{-1}$ ) at $0-5,5-10$, and $10-20 \mathrm{~cm}$ depths were calculated by multiplying their concentrations $\left(\mathrm{g} \cdot \mathrm{C} \cdot \mathrm{kg}^{-1}\right)$ by bulk density at each depth and thickness of the soil layer. Total content at $0-20 \mathrm{~cm}$ was determined by summing the contents at $0-5,5-10$, and $10-20 \mathrm{~cm}$.

\subsection{Data Analysis}

Data for crop biomass, surface residue, and soil $\mathrm{C}$ fractions at each depth were analyzed using the MIXED procedure of SAS, with year considered as the fixed effect [36]. Tillage, crop rotation, and cultural practice were considered as fixed effects and replication and tillage $\times$ replication as random effects. Since each phase of the crop rotation was present in every year, data for phases were averaged within a rotation and used for a crop rotation for the analysis. Means were separated by using the least square means test when treatments and interactions were significant [36]. Statistical significance was evaluated at $P \leq 0.05$, unless otherwise stated.

\section{Results and Discussion}

\subsection{Crop Biomass Yield}

Biomass (stems and leaves) yield varied between crop rotations from 2004 to 2007 (Table 2), as year and crop rotation $\times$ year interaction were significant $(P \leq 0.05)$ but tillage, cultural practice, and their interactions with crop rotation and year were not (data not shown). Biomass, averaged across tillage and cultural practices, was greater in W-B-C-P than in CW in 2004 and 2005. Biomass was greater in 2004 and 2006 than in 2005 in $\mathrm{CW}$ and greater in 2004 than in other years in W-B-C-P. Averaged across tillage, crop rotations, and cultural practices, biomass was greater in 2004 than in other years.

The greater biomass in W-B-C-P than in CW in 2004 and 2005 was due to higher corn yield. During these years, biomass in corn was two to three times greater than that in spring wheat, barley hay, and pea. Biomass was lower in 2005 than in other years, probably due to less uniform distribution and/or below-average precipitation. This was especially true for spring wheat in CW. Precipitation amounting to $115 \mathrm{~mm}$ fell in June but only $2 \mathrm{~mm}$ in September in 2005 compared to 68-yr average (72 $\mathrm{mm}$ in June and $34 \mathrm{~mm}$ in September) and other years. The growing season (April-October) precipitation was $11 \mathrm{~mm}$ greater in 2006 but $10 \mathrm{~mm}$ lower in 2005 than the normal precipitation $(311 \mathrm{~mm})$. Since dryland crop yields depend on the amount and distribution of precipitation due to the absence of irrigation, large variations in crop yields can occur from year to year due to variations in growing season precipitation $[3,5,12]$. Tillage and cultural practice did not influence biomass yield. Several researchers $[3,5,12]$ also found that tillage did not influence dryland crop biomass yield in the northern Great Plains. Since biomass, being a source of $\mathrm{C}$ input, was returned to the soil during grain harvest, the amount 
Table 2. Effect of crop rotation on crop biomass (stems and leaves) returned to the soil from 2004 to 2007.

\begin{tabular}{|c|c|c|c|}
\hline \multirow{2}{*}{ Year } & \multicolumn{3}{|c|}{ Crop rotation ${ }^{\mathrm{a}}$} \\
\hline & $\mathrm{CW}\left(\mathrm{Mg} \cdot \mathrm{ha}^{-1}\right)$ & W-B-C-P $\left(\mathrm{Mg} \cdot \mathrm{ha}^{-1}\right)$ & $\operatorname{Mean}\left(\mathrm{Mg} \cdot \mathrm{ha}^{-1}\right)$ \\
\hline 2004 & $5.40^{\mathrm{ab}} \mathrm{B}^{\mathrm{c}}$ & $6.71^{\mathrm{a} A}$ & $6.06^{\mathrm{a}}$ \\
\hline 2005 & $3.83^{\mathrm{b}} \mathrm{B}$ & $5.32^{\mathrm{b}} \mathrm{A}$ & $4.58^{\mathrm{c}}$ \\
\hline 2006 & $5.61^{\mathrm{a}} \mathrm{A}$ & $4.77^{\mathrm{b}} \mathrm{A}$ & $5.19^{\mathrm{b}}$ \\
\hline 2007 & $5.10^{\mathrm{ab}} \mathrm{A}$ & $5.31^{\mathrm{b}} \mathrm{A}$ & $5.21^{\mathrm{b}}$ \\
\hline
\end{tabular}

${ }^{\mathrm{a}}$ Crop rotations are $\mathrm{CW}$, continuous spring wheat; and W-B-C-P, spring wheat-barley hay-corn-pea; ${ }^{\mathrm{b}}$ Numbers followed by different lowercase letters within a column (among years) are significantly different at $P \leq 0.05$ by the least square means test; ${ }^{\mathrm{c}}$ Numbers followed by different uppercase letters within a row (between crop rotations) are significantly different at $P \leq 0.05$ by the least square means test.

of biomass as influenced by crop rotation can influence surface residue and soil $\mathrm{C}$ fractions, as discussed below.

\subsection{Soil Surface Residue Carbon}

Residue incorporation into the soil and mineralization due to tillage, cultural practice, and time resulted in significant tillage, year, and tillage $\times$ cultural practice interaction in surface residue amount and $\mathrm{C}$ content (Table 3 ). Surface residue amount, averaged across crop rotations and years, was greater in NT with the regular and ecological practices than in $\mathrm{CT}$ with the regular practice. Surface residue $\mathrm{C}$ was greater in NT than in CT in the regular practice. Averaged across crop rotations, cultural practices, and years, surface residue amount and $\mathrm{C}$ content were $27 \%$ to $30 \%$ greater in NT than in CT. Averaged across treatments, surface residue amount and $\mathrm{C}$ content declined from 51\% to 53\% from autumn 2007 to spring 2008. Surface residue between crop rotations did not vary, possibly because mean biomass across rotations was not different (Table 3).

The increased surface residue amount and $\mathrm{C}$ content in NT with the regular practice could be a result of reduced mineralization due to surface placement of the residue. In contrast, incorporation of the residue into the soil to a greater depth could have increased mineralization, thereby reducing surface residue amount and $\mathrm{C}$ content in $\mathrm{CT}$ with the regular practice [37]. Although crop biomass yield was not influenced by tillage and cultural practice, biomass was somewhat lower in the regular than in the ecological practice in CT, which could have resulted in lower surface residue amount and $\mathrm{C}$ content in this treatment. Surface residue amount and C content declined from autumn 2007 to spring 2008 probably due to increased mineralization and/or loss of residue due to the actions of wind and water. During this period, more than half of surface residue amount and $\mathrm{C}$ were lost, indicating that substantial losses of residue $\mathrm{C}$ can occur even during the cold weather in the winter. Increased surface residue amount can reduce soil erosion, increase $\mathrm{C}$ sequestration, and sustain dryland crop yields due to increased soil water conservation $[37,38]$. Since $C$ stored in surface residue form an important part of $\mathrm{C}$ cycle, management practices that increase surface residue $\mathrm{C}$ can also influence soil $\mathrm{C}$ fractions [37].

\subsection{Soil Organic Carbon}

Differences in crop residue quality and quantity and $\mathrm{C}$ mineralization rates among treatments also resulted in significant tillage $\times$ crop rotation $\times$ cultural practice interaction on SOC at $5-10,10-20$, and $0-20 \mathrm{~cm}$ (Table 4). At $10-20$ and $0-20 \mathrm{~cm}$, cultural practice, year, and tillage $\times$ crop rotation and tillage $\times$ cultural practice interactions were significant.

At $5-10 \mathrm{~cm}$, SOC, averaged across years, was greater in NT with CW and the ecological practice or in NT with W-B-C-P and the regular practice than in CT with CW and the ecological practice (Table 4). At $10-20 \mathrm{~cm}$, SOC was greater in NT with W-B-C-P and the regular practice than in NT with W-B-C-P and the ecological practice or in $\mathrm{CT}$ with $\mathrm{CW}$ and the regular and ecological practices. At $0-20 \mathrm{~cm}$, SOC was greater in NT with $\mathrm{CW}$ and the ecological practice or in NT with W-B-C-P and the regular practice than in NT with $\mathrm{W}-\mathrm{B}-\mathrm{C}-\mathrm{P}$ and the ecological practice or in $\mathrm{CT}$ with $\mathrm{CW}$ and the ecological practice. Averaged across tillage, crop rotations, and years, SOC at $10-20$ and $0-20 \mathrm{~cm}$ was $2.4 \%$ to $4.3 \%$ greater with the regular than with the ecological practice. Averaged across treatments, SOC at $10-20$ and $0-20$ $\mathrm{cm}$ reduced by $3.7 \%$ to $4.8 \%$, respectively from autumn 2007 to spring 2008.

Changes in SOC due to treatments occurred mostly at the subsurface than in the surface soil. This was kind of a surprise given the residue accumulation at the surface due to NT and incorporation into the soil due to CT occurred to a depth $<10 \mathrm{~cm}$. While the coefficient of variation for SOC ranged from $8.6 \%$ in 2007 to $9.1 \%$ in 2008 at $0-5 \mathrm{~cm}$, it ranged from $8.5 \%$ in 2007 to $10.0 \%$ in 2008 at $5-10$ and $10-20 \mathrm{~cm}$. Since the variability in SOC at the surface and subsurface layers were similar, it could be possible that differences in the amount of residue incorporation into the soil due to $\mathrm{CT}$ and/or root growth among treatments resulted in SOC changes more in the subsurface than in the surface soil.

The greater SOC at $5-10,10-20$, and $0-20 \mathrm{~cm}$ in 
Table 3. Effects of tillage and cultural practice on soil surface residue amount and C content in 2007 and 2008.

\begin{tabular}{|c|c|c|c|c|}
\hline \multirow{2}{*}{ Tillage $^{a}$} & \multirow{2}{*}{ Cultural practice ${ }^{\mathrm{b}}$} & \multirow{2}{*}{ Year } & \multicolumn{2}{|c|}{ Soil surface residue } \\
\hline & & & Amount $\left(\mathrm{Mg} \cdot \mathrm{ha}^{-1}\right)$ & $\mathrm{C}$ content $\left(\mathrm{Mg} \cdot \mathrm{C} \cdot \mathrm{ha}^{-1}\right)$ \\
\hline \multirow[t]{2}{*}{ NT } & Regular & & 4.04 & 1.50 \\
\hline & Ecological & & 3.71 & 1.36 \\
\hline \multirow[t]{2}{*}{ CT } & Regular & & 2.72 & 1.03 \\
\hline & Ecological & & 3.21 & 1.22 \\
\hline $\operatorname{LSD}(0.05)$ & & & 0.99 & 0.40 \\
\hline \multicolumn{5}{|l|}{ Means } \\
\hline NT & & & $3.87 \mathrm{a}^{\mathrm{c}}$ & $1.43 \mathrm{a}$ \\
\hline \multirow[t]{3}{*}{$\mathrm{CT}$} & & & $2.97 \mathrm{~b}$ & $1.13 b$ \\
\hline & & 2007 & $4.64 \mathrm{a}$ & $1.72 \mathrm{a}$ \\
\hline & & 2008 & $2.26 \mathrm{~b}$ & $0.81 \mathrm{~b}$ \\
\hline \multicolumn{5}{|l|}{ Significance $^{\mathrm{d}}$} \\
\hline Tillage (T) & & & $*$ & $*$ \\
\hline Crop rotation $(\mathrm{C})$ & & & NS & NS \\
\hline $\mathrm{T} \times \mathrm{C}$ & & & NS & NS \\
\hline Cultural practice $(\mathrm{P})$ & & & NS & NS \\
\hline $\mathrm{T} \times \mathrm{P}$ & & & * & $*$ \\
\hline $\mathrm{C} \times \mathrm{P}$ & & & NS & NS \\
\hline $\mathrm{T} \times \mathrm{C} \times \mathrm{P}$ & & & NS & NS \\
\hline Year (Y) & & & *** & $* * *$ \\
\hline $\mathrm{T} \times \mathrm{Y}$ & & & NS & NS \\
\hline $\mathrm{C} \times \mathrm{Y}$ & & & NS & NS \\
\hline $\mathrm{T} \times \mathrm{C} \times \mathrm{Y}$ & & & NS & NS \\
\hline $\mathrm{P} \times \mathrm{Y}$ & & & NS & NS \\
\hline $\mathrm{T} \times \mathrm{P} \times \mathrm{Y}$ & & & NS & NS \\
\hline $\mathrm{C} \times \mathrm{P} \times \mathrm{Y}$ & & & NS & NS \\
\hline $\mathrm{T} \times \mathrm{C} \times \mathrm{P} \times \mathrm{Y}$ & & & NS & NS \\
\hline
\end{tabular}

${ }^{\mathrm{a}}$ Tillage practices are CT, conventional tillage; and NT, no-tillage; ${ }^{\mathrm{b}}$ See Table 2 for the description of cultural practices; ${ }^{\mathrm{c}}$ Numbers followed by different letters within a column in either tillage practice or year are significantly different at $P \leq 0.05$ by the least square means test; ${ }^{\mathrm{d}}$ Significance levels: ${ }^{*} P \leq 0.05 ;{ }^{* * *} P \leq 0.01$; ${ }_{* * *}^{*} P \leq 0.001 ;$ NS, Not significant.

NT with CW and the ecological practice or in NT with W-B-C-P and the regular practice than in $\mathrm{CT}$ with $\mathrm{CW}$ and the regular and ecological practices could be the results of increased crop residue returned to the soil, followed by decreased mineralization of residue and soil organic matter due to reduced soil disturbance. Crop biomass returned to the soil was greater in W-B-C-P than in CW in 2004 and 2005 (Table 2). While CT can reduce dryland soil C storage compared to NT $[5,9,25]$, increased residue returned to the soil due to diversified crop rotation and increased cropping intensity can increase SOC levels [3-5]. The lower SOC at $10-20$ and 0 $-20 \mathrm{~cm}$ in the ecological than in the regular practice was probably due to increased organic matter mineralization as a result of longer fallow period from delayed planting. The lower bulk density in the ecological practice also may have partly contributed to lower SOC in this treatment. During the fallow period in the winter, SOC did not change at $0-5$ and $5-10 \mathrm{~cm}$ but declined at $10-20$ $\mathrm{cm}$, possibly a result of absence of crop residue input and/or increased mineralization of SOC and residue in the subsurface compared to the surface layers. Because of differences in SOC levels from autumn to spring at the subsurface soil layer, it may be a good idea to collect soil samples at the same time of the year for SOC analysis if deeper samples $>10 \mathrm{~cm}$ are collected.

The SOC level at $0-20 \mathrm{~cm}$ at the initiation of the experiment in April 2004 was $30.5 \mathrm{Mg} \cdot \mathrm{ha}^{-1}$. The SOC levels at $0-20 \mathrm{~cm}$ between 2007 and 2008 ranged from $28.0 \mathrm{Mg} \cdot \mathrm{C} \cdot \mathrm{ha}^{-1}$ in CT with $\mathrm{CW}$ and the ecological practice to $31.2 \mathrm{Mg} \cdot \mathrm{C} \cdot \mathrm{ha}^{-1}$ in NT with $\mathrm{CW}$ and the ecological practice (Table 4). This suggests that SOC decreased by 
Table 4. Effects of tillage, crop rotation, and cultural practice on soil organic C (SOC) content at the 0 - $20 \mathrm{~cm}$ depth in 2007 and 2008.

\begin{tabular}{|c|c|c|c|c|c|c|c|}
\hline \multirow{2}{*}{ Tillage $^{\mathrm{a}}$} & \multirow{2}{*}{ Crop rotation ${ }^{\mathrm{b}}$} & \multirow{2}{*}{ Cultural practice $^{c}$} & \multirow{2}{*}{ Year } & \multicolumn{4}{|c|}{ SOC content $\left(\mathrm{Mg} \cdot \mathrm{C} \cdot \mathrm{ha}^{-1}\right)$} \\
\hline & & & & $0-5 \mathrm{~cm}$ & $5-10 \mathrm{~cm}$ & $10-20 \mathrm{~cm}$ & $0-20 \mathrm{~cm}$ \\
\hline \multirow[t]{4}{*}{ NT } & $\mathrm{CW}$ & Regular & & 8.1 & 7.2 & 14.8 & 30.1 \\
\hline & & Ecological & & 8.7 & 7.9 & 14.6 & 31.2 \\
\hline & W-B-C-P & Regular & & 8.2 & 7.7 & 15.1 & 31.0 \\
\hline & & Ecological & & 8.2 & 7.2 & 13.2 & 28.6 \\
\hline \multirow[t]{4}{*}{$\mathrm{CT}$} & $\mathrm{CW}$ & Regular & & 8.4 & 7.1 & 14.0 & 29.5 \\
\hline & & Ecological & & 8.0 & 6.8 & 13.3 & 28.1 \\
\hline & W-B-C-P & Regular & & 8.1 & 7.4 & 14.3 & 29.8 \\
\hline & & Ecological & & 8.0 & 7.3 & 14.6 & 29.9 \\
\hline $\operatorname{LSD}(0.05)$ & & & & NS & 0.7 & 1.0 & 2.1 \\
\hline \multicolumn{8}{|l|}{ Mean } \\
\hline & & Regular & & $8.2^{\mathrm{ad}}$ & $7.3^{\mathrm{a}}$ & $14.5^{\mathrm{a}}$ & $30.0^{\mathrm{a}}$ \\
\hline & & Ecological & & $8.2^{\mathrm{a}}$ & $7.3^{\mathrm{a}}$ & $13.9^{\mathrm{b}}$ & $29.4^{\mathrm{b}}$ \\
\hline & & & 2007 & $8.3^{\mathrm{a}}$ & $7.4^{\mathrm{a}}$ & $14.6^{\mathrm{a}}$ & $30.3^{\mathrm{a}}$ \\
\hline & & & 2008 & $8.1^{\mathrm{a}}$ & $7.1^{\mathrm{a}}$ & $13.9^{\mathrm{b}}$ & $29.1^{\mathrm{b}}$ \\
\hline \multicolumn{8}{|c|}{ Significance $^{e}$} \\
\hline Tillage (T) & & & & $\mathrm{NS}^{\mathrm{b}}$ & NS & NS & NS \\
\hline \multicolumn{2}{|c|}{ Crop rotation (C) } & & & NS & NS & NS & NS \\
\hline \multirow{2}{*}{\multicolumn{2}{|c|}{ Cultural practice $(\mathrm{P})$}} & & & NS & NS & ** & * \\
\hline & & & & NS & NS & *** & ** \\
\hline \multicolumn{2}{|c|}{$\mathrm{T} \times \mathrm{P}$} & & & NS & NS & *** & $*$ \\
\hline \multicolumn{2}{|l|}{$\mathrm{C} \times \mathrm{P}$} & & & NS & NS & NS & NS \\
\hline \multicolumn{2}{|l|}{$\mathrm{T} \times \mathrm{C} \times \mathrm{P}$} & & & NS & * & ${ }^{* *}$ & $* * *$ \\
\hline \multicolumn{2}{|l|}{ Year (Y) } & & & NS & NS & $* * *$ & $* *$ \\
\hline \multicolumn{2}{|l|}{$\mathrm{T} \times \mathrm{Y}$} & & & NS & NS & NS & NS \\
\hline \multicolumn{2}{|l|}{$\mathrm{C} \times \mathrm{Y}$} & & & NS & NS & NS & NS \\
\hline \multicolumn{2}{|l|}{$\mathrm{T} \times \mathrm{C} \times \mathrm{Y}$} & & & NS & NS & NS & NS \\
\hline \multicolumn{2}{|l|}{$\mathrm{P} \times \mathrm{Y}$} & & & NS & NS & NS & NS \\
\hline \multicolumn{2}{|l|}{$\mathrm{T} \times \mathrm{P} \times \mathrm{Y}$} & & & NS & NS & NS & NS \\
\hline \multicolumn{2}{|l|}{$\mathrm{C} \times \mathrm{P} \times \mathrm{Y}$} & & & NS & NS & NS & NS \\
\hline \multicolumn{2}{|c|}{$\mathrm{T} \times \mathrm{C} \times \mathrm{P} \times \mathrm{Y}$} & & & NS & NS & NS & NS \\
\hline
\end{tabular}

${ }^{\mathrm{a}}$ Tillage practices are $\mathrm{CT}$, conventional tillage; and NT, no-tillage; ${ }^{\mathrm{b}} \mathrm{Crop}$ rotations are $\mathrm{CW}$, continuous spring wheat; and W-B-C-P, spring wheat-barley hay-corn-pea.; ${ }^{\mathrm{c}}$ See Table 2 for the description of cultural practices; ${ }^{\mathrm{d}}$ Numbers followed by different letters within a column in either cultural practice or year are significantly different at $P \leq 0.05$ by the least square means test; ${ }^{\text {e }}$ Significance levels: ${ }^{*} P \leq 0.05 ;{ }^{* *} P \leq 0.01 ;{ }^{* * *} P \leq 0.001 ;$ NS, Not significant.

$500 \mathrm{~kg} \cdot \mathrm{C} \cdot \mathrm{ha}^{-1} \cdot \mathrm{yr}^{-1}$ in $\mathrm{CT}$ with $\mathrm{CW}$ and the ecological practice but increased by $140 \mathrm{~kg} \cdot \mathrm{C} \cdot \mathrm{ha}^{-1} \cdot \mathrm{yr}^{-1}$ in NT with $\mathrm{CW}$ and the ecological practice. The loss in SOC from 2004 to 2008 in CT with CW and the ecological practice is larger than the reported value $141 \mathrm{~kg} \cdot \mathrm{C} \cdot \mathrm{ha}^{-1} \cdot \mathrm{yr}^{-1}$ in CT with crop-fallow but the gain in NT with $\mathrm{CW}$ and the ecological practice is smaller than $233 \mathrm{~kg} \cdot \mathrm{C} \cdot \mathrm{ha}^{-1} \cdot \mathrm{yr}^{-1}$ in NT with continuous cropping under dryland farming system in the northern Great Plains [9]. Possibly, the experiment needs to be continued for more than five years to obtain a stable $\mathrm{C}$ sequestration rate, since several researchers $[3,37,39]$ have concluded the need for long- term experiment on $\mathrm{C}$ sequestration to observe the effects of management practices on soil $\mathrm{C}$ storage under dryland cropping systems in the northern Great Plains. This is because lower crop biomass returned to the soil due to limited precipitation compared with humid regions and cold weather reduces turnover rate of plant $\mathrm{C}$ into $\mathrm{SOC}$ $[3,5]$.

\subsection{Soil Particulate Organic Carbon}

Similar to SOC, POC content varied between cultural practices at $5-10$ and $10-20 \mathrm{~cm}$ and between years at 
all depths (Table 5). Interactions were significant for tillage $\times$ year at $5-10 \mathrm{~cm}$, crop rotation $\times$ year at $10-20$ $\mathrm{cm}$, and tillage $\times$ crop rotation $\times$ year at $0-5,10-20$, and $0-20 \mathrm{~cm}$.

The POC at $0-5,10-20$, and $0-20 \mathrm{~cm}$, averaged across cultural practices, was greater in NT with $\mathrm{CW}$ than in other tillage and crop rotations in 2007 (Table 5). In 2008, POC at $10-20 \mathrm{~cm}$ was greater in W-B-C-P than in $\mathrm{CW}$ in CT but at other depths, it was not different between tillage and crop rotations. From autumn 2007 to spring 2008, POC at $0-5$ and $0-20 \mathrm{~cm}$ declined rapidly in NT with CW and CT with W-B-C-P compared to other treatments. Similarly, during this period, $\mathrm{POC}$ at 10 - $20 \mathrm{~cm}$ declined more in NT with CW or W-B-C-P than in other treatments. Averaged POC across treatments, however, declined from $16 \%$ to $18 \%$ at all depths from autumn 2007 to spring 2008. Averaged across tillage, crop rotations, and years, $\mathrm{POC}$ at $5-10$ and $10-20 \mathrm{~cm}$ was greater in the regular than in ecological practice.

As with SOC, greater POC at $0-5,10-20$, and $0-20$ $\mathrm{cm}$ in NT with CW than in other tillage and crop rotations in 2007 could be the results of an undisturbed soil

Table 5. Effects of tillage, crop rotation, and cultural practice on soil particulate organic C (POC) content at the 0 - $20 \mathrm{~cm}$ depth in 2007 and 2008.

\begin{tabular}{|c|c|c|c|c|c|c|c|}
\hline \multirow{2}{*}{ Year } & \multirow{2}{*}{ Tillage $^{a}$} & \multirow{2}{*}{ Crop rotation ${ }^{b}$} & \multirow{2}{*}{ Cultural practice $^{\mathrm{c}}$} & \multicolumn{4}{|c|}{ POC content $\left(\mathrm{Mg} \mathrm{C} \cdot \mathrm{ha}^{-1}\right)$} \\
\hline & & & & $0-5 \mathrm{~cm}$ & $5-10 \mathrm{~cm}$ & $10-20 \mathrm{~cm}$ & $0-20 \mathrm{~cm}$ \\
\hline \multirow[t]{4}{*}{2007} & NT & $\mathrm{CW}$ & & 2.49 & 1.77 & 3.56 & 7.82 \\
\hline & & W-B-C-P & & 2.04 & 1.57 & 2.96 & 6.57 \\
\hline & $\mathrm{CT}$ & $\mathrm{CW}$ & & 2.00 & 1.58 & 2.90 & 6.48 \\
\hline & & W-B-C-P & & 2.14 & 1.69 & 2.91 & 6.74 \\
\hline \multirow[t]{4}{*}{2008} & NT & $\mathrm{CW}$ & & 1.84 & 1.50 & 2.52 & 5.86 \\
\hline & & W-B-C-P & & 1.86 & 1.52 & 2.55 & 5.93 \\
\hline & $\mathrm{CT}$ & $\mathrm{CW}$ & & 1.86 & 1.30 & 2.28 & 5.44 \\
\hline & & W-B-C-P & & 1.64 & 1.26 & 2.76 & 5.66 \\
\hline $\operatorname{LSD}(0.05)$ & & & & 0.28 & NS & 0.48 & 0.82 \\
\hline \multicolumn{8}{|l|}{ Mean } \\
\hline 2007 & & & & $2.16^{\mathrm{ad}}$ & $1.65^{\mathrm{a}}$ & $3.08^{\mathrm{a}}$ & $6.89^{\mathrm{a}}$ \\
\hline \multirow[t]{3}{*}{2008} & & & & $1.80^{\mathrm{b}}$ & $1.39^{\mathrm{b}}$ & $2.53^{\mathrm{b}}$ & $5.72^{\mathrm{b}}$ \\
\hline & & & Regular & $1.99^{\mathrm{a}}$ & $1.55^{\mathrm{a}}$ & $2.88^{\mathrm{a}}$ & $6.42^{\mathrm{a}}$ \\
\hline & & & Ecological & $1.98^{\mathrm{a}}$ & $1.49^{\mathrm{b}}$ & $2.73^{\mathrm{b}}$ & $6.20^{\mathrm{a}}$ \\
\hline \multicolumn{8}{|c|}{ Significance $^{\mathrm{e}}$} \\
\hline Tillage ( $\mathrm{T})$ & & & & NS & NS & NS & NS \\
\hline \multicolumn{2}{|c|}{ Crop rotation $(\mathrm{C})$} & & & NS & NS & NS & NS \\
\hline \multicolumn{2}{|l|}{$\mathrm{T} \times \mathrm{C}$} & & & NS & NS & NS & NS \\
\hline \multicolumn{2}{|c|}{ Cultural practice $(\mathrm{P})$} & & & NS & $*$ & * & NS \\
\hline \multicolumn{2}{|l|}{$\mathrm{T} \times \mathrm{P}$} & & & NS & NS & NS & NS \\
\hline \multicolumn{2}{|l|}{$\mathrm{C} \times \mathrm{P}$} & & & NS & NS & NS & NS \\
\hline \multicolumn{2}{|l|}{$\mathrm{T} \times \mathrm{C} \times \mathrm{P}$} & & & NS & NS & NS & NS \\
\hline \multicolumn{2}{|l|}{ Year (Y) } & & & $* * *$ & $* * *$ & $* * *$ & $* * *$ \\
\hline \multicolumn{2}{|l|}{$\mathrm{T} \times \mathrm{Y}$} & & & NS & * & NS & NS \\
\hline \multicolumn{2}{|l|}{$\mathrm{C} \times \mathrm{Y}$} & & & NS & NS & $*$ & NS \\
\hline \multicolumn{2}{|l|}{$\mathrm{T} \times \mathrm{C} \times \mathrm{Y}$} & & & $* *$ & NS & * & ${ }^{*}$ \\
\hline \multicolumn{2}{|l|}{$\mathrm{P} \times \mathrm{Y}$} & & & NS & NS & NS & NS \\
\hline \multicolumn{2}{|l|}{$\mathrm{T} \times \mathrm{P} \times \mathrm{Y}$} & & & NS & NS & NS & NS \\
\hline \multicolumn{2}{|l|}{$\mathrm{C} \times \mathrm{P} \times \mathrm{Y}$} & & & NS & NS & NS & NS \\
\hline \multicolumn{2}{|c|}{$\mathrm{T} \times \mathrm{C} \times \mathrm{P} \times \mathrm{Y}$} & & & NS & NS & NS & NS \\
\hline
\end{tabular}

${ }^{\mathrm{a}}$ Tillage practices are CT, conventional tillage; and NT, no-tillage; ${ }^{\mathrm{b}} \mathrm{Crop}$ rotations are $\mathrm{CW}$, continuous spring wheat; and W-B-C-P, spring wheat-barley hay-corn-pea; ${ }^{\mathrm{C}} \mathrm{See}$ Table 2 for the description of cultural practices; ${ }^{\mathrm{d}}$ Numbers followed by different letters within a column in either year or cultural practice are significantly different at $P \leq 0.05$ by the least square means test; ${ }^{\circ}$ Significance levels: ${ }^{*} P \leq 0.05 ;{ }^{* *} P \leq 0.01 ;{ }^{* * *} P \leq 0.001$; NS, Not significant. 
and surface placement of residue that reduced the mineralization of residue and coarse soil organic matter. The greater POC level with this treatment was, however, short lived because greater rate of decline in its level occurred in NT with $\mathrm{CW}$ than in other treatments from 2007 to 2008, thereby resulting in non-significant difference in POC between treatments at all depths, except at $10-20 \mathrm{~cm}$, in 2008. This indicates that coarse fraction of soil organic matter can be enriched by using no-tillage with continuous spring wheat compared to conventional tillage with monocropping or crop rotation but the level was reduced from autumn to the following spring, probably by increased mineralization. The proportion of SOC in POC at $0-20 \mathrm{~cm}$ was also greater in NT with CW (226 g $\cdot$ POC $\left.\cdot \mathrm{kg}^{-1} \mathrm{SOC}\right)$ than in other tillage and crop rotations (207 to $208 \mathrm{~g} \cdot \mathrm{POC} \cdot \mathrm{kg}^{-1} \mathrm{SOC}$ ) in 2007 but was not significantly different among treatments in 2008. This suggests that coarse organic matter was mineralized at a rapid rate compared to whole soil organic matter, a case similar to that observed by other researchers $[5,18$, $22,40]$.

The lower POC in the ecological than in the regular practice at the subsurface layers $(5-10$ and $10-20 \mathrm{~cm}$ ) could be the results of increased mineralization of coarse organic matter due to longer fallow period and/or reduced residue input due to delayed planting, a case similar to that observed for SOC. As with SOC, changes in POC occurred more at the subsurface than in surface layers. Probably differences in crop root growth and/or various levels of residue incorporation to a greater depth due to tillage (e.g. greater spring wheat stubble height [Table 2] reduced the amount of residue incorporation into the soil in the ecological than in the regular practice) influenced POC levels between the two cultural practices more in the subsurface than in the surface soil.

\subsection{Soil Potential Carbon Mineralization}

The PCM content varied between years at all depths, except at $10-20 \mathrm{~cm}$. (Table 6). Interactions were significant for tillage $\times$ year at all depths and tillage $\times$ cultural practice $\times$ year at $5-10,10-20$, and $0-20 \mathrm{~cm}$. Crop rotation and its interaction with other treatments were not significant.

The PCM at $5-10 \mathrm{~cm}$, averaged across crop rotations, was greater in NT with the regular practice than in CT with the ecological practice in 2007 (Table 6). At $10-20$ and $0-20 \mathrm{~cm}, \mathrm{PCM}$ was greater in NT with the regular practice than in CT with the regular and ecological practices. In 2008, PCM at $0-20 \mathrm{~cm}$ was greater in NT with the regular practice than in $\mathrm{CT}$ with the regular practice. From autumn 2007 to spring 2008, PCM at $5-10$ and 10 - $20 \mathrm{~cm}$ declined rapidly in NT with the regular practice compared to other treatments, thereby resulting in nonsignificant difference among tillage and cultural practices in 2008. Averaged across crop rotations and cultural practices, PCM was greater in NT than in CT at all depths in 2007 and at $0-20 \mathrm{~cm}$ in 2008. In contrast to SOC and POC, PCM at all depths, averaged across treatments, declined from $17 \%$ to $34 \%$ from autumn 2007 to spring 2008.

The greater PCM in NT with the regular practice than in CT with the regular and ecological practices was probably a result of greater substrate availability, since SOC and POC were greater in this treatment (Tables 4 and 5). This is consistent with those reported by several researchers $[18,21,40]$ who found that greater substrate availability increased $\mathrm{C}$ mineralization and microbial activity in NT than in CT. Increased C mineralization due to residue incorporation into the soil, followed by longer duration of fallow probably reduced PCM in CT with the regular and ecological practices. As with SOC and POC, greater level of PCM in NT with the regular practice was short lived, as substrate availability declined at a rapid rate with this treatment from autumn 2007 to spring 2008. Since PCM declined both at the surface and subsurface soil layers at higher rates during this period in contrast to slower rate of decline for SOC and POC at the subsurface layers, PCM could be a sensitive indicator of changes in soil organic matter with management practice and time, a case similar to those observed by various researchers $[20,21]$. Although variability was higher in PCM (CV 28\% - 55\%) than in SOC and POC (CV 7\% $25 \%$ ), small changes in SOC and POC levels due to management practices and mineralization with time resulted in large changes in PCM level.

\subsection{Soil Microbial Biomass Carbon}

Like SOC and POC, changes in MBC occurred at the subsurface layers, with significant interactions for tillage $\times$ crop rotation $\times$ year at $0-20 \mathrm{~cm}$, cultural practice $\times$ year at $5-10 \mathrm{~cm}$, and tillage $\times$ crop rotation $\times$ cultural practice $\times$ year at $10-20$ and $0-20 \mathrm{~cm}$ (Table 7). The $\mathrm{MBC}$, however, varied significantly with crop rotation and years at all depths. The variability was lower for MBC (CV 15\% - 40\%) than for PCM but greater than for SOC and POC.

In 2007, MBC at $10-20 \mathrm{~cm}$ was greater in NT with $\mathrm{CW}$ and the regular practice than in NT with $\mathrm{CW}$ and the ecological practice, NT with W-B-C-P and the ecological practice, or in $\mathrm{CT}$ with $\mathrm{CW}$ and the regular practice (Table 7). At $0-20 \mathrm{~cm}, \mathrm{MBC}$ was greater in NT with $\mathrm{CW}$ and the regular practice than in NT with $\mathrm{CW}$ and the ecological practice or in $\mathrm{CT}$ with $\mathrm{CW}$ and the regular practice. From 2007 to $2008, \mathrm{MBC}$ at $10-20$ and $0-20$ $\mathrm{cm}$ declined rapidly in NT with $\mathrm{CW}$ and the regular practice and CT with $\mathrm{CW}$ or W-B-C-P with the ecological practice compared to other treatments, thereby resulting in non-significant difference between treatments in 2008 . 
Table 6. Effects of tillage and cultural practice on soil potential C mineralization (PCM) content at the 0 - $20 \mathrm{~cm}$ depth in 2007 and 2008.

\begin{tabular}{|c|c|c|c|c|c|c|}
\hline \multirow{2}{*}{ Year } & \multirow{2}{*}{ Tillage $^{\mathrm{a}}$} & \multirow{2}{*}{ Cultural practice $^{\mathrm{b}}$} & \multicolumn{4}{|c|}{ PCM content $\left(\mathrm{kg} \cdot \mathrm{C} \cdot \mathrm{ha}^{-1}\right)$} \\
\hline & & & $0-5 \mathrm{~cm}$ & $5-10 \mathrm{~cm}$ & $10-20 \mathrm{~cm}$ & $0-20 \mathrm{~cm}$ \\
\hline \multirow[t]{4}{*}{2007} & NT & Regular & 39 & 35 & 78 & 152 \\
\hline & & Ecological & 42 & 32 & 60 & 134 \\
\hline & $\mathrm{CT}$ & Regular & 33 & 25 & 47 & 105 \\
\hline & & Ecological & 28 & 23 & 50 & 101 \\
\hline \multirow[t]{4}{*}{2008} & NT & Regular & 24 & 18 & 43 & 85 \\
\hline & & Ecological & 24 & 19 & 52 & 95 \\
\hline & $\mathrm{CT}$ & Regular & 31 & 20 & 52 & 103 \\
\hline & & Ecological & 30 & 19 & 50 & 99 \\
\hline $\operatorname{LSD}(0.05)$ & & & NS & 12 & 28 & 48 \\
\hline \multicolumn{7}{|l|}{ Mean } \\
\hline 2007 & & & $36^{\mathrm{ac}}$ & $29^{\mathrm{a}}$ & $59^{\mathrm{a}}$ & $124^{\mathrm{a}}$ \\
\hline 2008 & & & $27^{\mathrm{b}}$ & $19^{\mathrm{b}}$ & $49^{\mathrm{a}}$ & $95^{\mathrm{b}}$ \\
\hline \multicolumn{7}{|l|}{ Significance $^{\mathrm{d}}$} \\
\hline Tillage (T) & & & NS & NS & NS & NS \\
\hline Crop rotation $(\mathrm{C})$ & & & NS & NS & NS & NS \\
\hline $\mathrm{T} \times \mathrm{C}$ & & & NS & NS & NS & NS \\
\hline Cultural practice $(\mathrm{P})$ & & & NS & NS & NS & NS \\
\hline $\mathrm{T} \times \mathrm{P}$ & & & NS & NS & NS & NS \\
\hline $\mathrm{C} \times \mathrm{P}$ & & & NS & NS & NS & NS \\
\hline $\mathrm{T} \times \mathrm{C} \times \mathrm{P}$ & & & NS & NS & NS & NS \\
\hline Year (Y) & & & $*$ & $*$ & NS & $*$ \\
\hline $\mathrm{T} \times \mathrm{Y}$ & & & $*$ & $*$ & * & $* *$ \\
\hline $\mathrm{C} \times \mathrm{Y}$ & & & NS & NS & NS & NS \\
\hline $\mathrm{T} \times \mathrm{C} \times \mathrm{Y}$ & & & NS & NS & NS & NS \\
\hline $\mathrm{P} \times \mathrm{Y}$ & & & NS & NS & NS & NS \\
\hline $\mathrm{T} \times \mathrm{P} \times \mathrm{Y}$ & & & NS & ${ }^{*}$ & $*$ & $*$ \\
\hline $\mathrm{C} \times \mathrm{P} \times \mathrm{Y}$ & & & NS & NS & NS & NS \\
\hline $\mathrm{T} \times \mathrm{C} \times \mathrm{P} \times \mathrm{Y}$ & & & NS & NS & NS & NS \\
\hline
\end{tabular}

${ }^{\mathrm{a}}$ Tillage practices are CT, conventional tillage; and NT, no-tillage; ${ }^{\mathrm{b}}$ See Table 2 for the description of cultural practices; ${ }^{\mathrm{c}}$ Numbers followed by different letters within a column in a year are significantly different at $P \leq 0.05$ by the least square means test; ${ }^{\mathrm{d}}$ Significance levels: ${ }^{*} P \leq 0.05 ;{ }^{* * *} P \leq 0.01 ;{ }^{* * *} P \leq 0.001 ; \mathrm{NS}$, Not significant.

Averaged across tillage, cultural practices, and years, MBC at all depths was $11 \%$ to $14 \%$ greater in W-B-C-P than in CW. Similar to PCM, MBC at all depths, averaged across treatments, declined from $22 \%$ to $24 \%$ from autumn 2007 to spring 2008.

Greater substrate availability due to increased SOC and POC probably increased MBC in NT with CW and the regular practice at the subsurface soil in 2007. As the substrate availability decreased, MBC also declined from 2007 to 2008. Similar to PCM, MBC decline occurred at all depths, with a greater rate of decline than in SOC and POC. This verifies that $\mathrm{MBC}$ is also an active fraction of soil organic matter [20,21]. Diversified crop rotation clearly increased $\mathrm{MBC}$ in $\mathrm{W}-\mathrm{B}-\mathrm{C}-\mathrm{P}$ than in $\mathrm{CW}$, which was especially noted in CT in 2007. Increased amount of crop residue returned to the soil (Table 2) probably increased MBC in W-B-C-P compared to CW. Several researchers $[4,26,40]$ also reported that $\mathrm{MBC}$ increased with diversified crop rotation compared to monocropping due to increased crop residue returned to the soil.

\section{Conclusion}

Differences in tillage, crop rotations, and cultural practices among treatments influenced crop biomass (stems and leaves) returned to the soil, surface residue, and soil $\mathrm{C}$ fractions. In contrast to our hypothesis, no-tillage with monocropping and the regular cultural practice increased 
Table 7. Effects of tillage, crop rotation, and cultural practice on soil microbial biomass C (MBC) content at the 0 - $20 \mathrm{~cm}$ depth in 2007 and 2008.

\begin{tabular}{|c|c|c|c|c|c|c|c|}
\hline \multirow{2}{*}{ Year } & \multirow{2}{*}{ Tillage $^{a}$} & \multirow{2}{*}{ Cultural practice $^{\mathrm{b}}$} & \multirow{2}{*}{ Crop rotation ${ }^{\mathrm{c}}$} & \multicolumn{4}{|c|}{ MBC content $\left(\mathrm{kg} \cdot \mathrm{C} \cdot \mathrm{ha}^{-1}\right)$} \\
\hline & & & & $0-5 \mathrm{~cm}$ & $5-10 \mathrm{~cm}$ & $10-20 \mathrm{~cm}$ & $0-20 \mathrm{~cm}$ \\
\hline \multirow[t]{8}{*}{2007} & NT & Regular & $\mathrm{CW}$ & 99 & 79 & 196 & 374 \\
\hline & & & W-B-C-P & 94 & 73 & 167 & 334 \\
\hline & & Ecological & $\mathrm{CW}$ & 101 & 72 & 115 & 288 \\
\hline & & & W-B-C-P & 106 & 79 & 153 & 338 \\
\hline & $\mathrm{CT}$ & Regular & $\mathrm{CW}$ & 82 & 54 & 120 & 256 \\
\hline & & & W-B-C-P & 101 & 79 & 180 & 360 \\
\hline & & Ecological & $\mathrm{CW}$ & 84 & 61 & 165 & 310 \\
\hline & & & W-B-C-P & 111 & 85 & 184 & 380 \\
\hline \multirow[t]{8}{*}{2008} & NT & Regular & $\mathrm{CW}$ & 59 & 58 & 114 & 231 \\
\hline & & & W-B-C-P & 85 & 57 & 135 & 277 \\
\hline & & Ecological & $\mathrm{CW}$ & 93 & 52 & 108 & 253 \\
\hline & & & W-B-C-P & 79 & 60 & 114 & 253 \\
\hline & $\mathrm{CT}$ & Regular & $\mathrm{CW}$ & 67 & 61 & 129 & 257 \\
\hline & & & W-B-C-P & 80 & 65 & 121 & 266 \\
\hline & & Ecological & $\mathrm{CW}$ & 67 & 52 & 122 & 241 \\
\hline & & & W-B-C-P & 78 & 56 & 128 & 262 \\
\hline \multicolumn{2}{|c|}{$\operatorname{LSD}(0.05)$} & & & NS & NS & 38 & 59 \\
\hline \multicolumn{8}{|c|}{ Mean } \\
\hline \multicolumn{2}{|c|}{2007} & & & $97^{\text {ad }}$ & $73^{\mathrm{a}}$ & $160^{\mathrm{a}}$ & $330^{\mathrm{a}}$ \\
\hline \multirow{3}{*}{\multicolumn{2}{|c|}{2008}} & & & $76^{\mathrm{b}}$ & $57^{\mathrm{b}}$ & $122^{\mathrm{b}}$ & $255^{\mathrm{b}}$ \\
\hline & & & $\mathrm{CW}$ & $81^{\mathrm{b}}$ & $61^{\mathrm{b}}$ & $134^{\mathrm{b}}$ & $276^{\mathrm{b}}$ \\
\hline & & & W-B-C-P & $92^{\mathrm{a}}$ & $68^{\mathrm{a}}$ & $148^{\mathrm{a}}$ & $308^{\mathrm{a}}$ \\
\hline \multicolumn{8}{|c|}{ Significance $^{e}$} \\
\hline \multicolumn{2}{|c|}{ Tillage (T) } & & & NS & NS & NS & NS \\
\hline \multicolumn{2}{|c|}{ Crop rotation $(\mathrm{C})$} & & & * & * & * & $* *$ \\
\hline \multicolumn{2}{|l|}{$\mathrm{T} \times \mathrm{C}$} & & & NS & NS & NS & NS \\
\hline \multicolumn{2}{|c|}{ Cultural practice $(\mathrm{P})$} & & & NS & NS & NS & NS \\
\hline \multicolumn{2}{|l|}{$\mathrm{T} \times \mathrm{P}$} & & & NS & NS & $* *$ & NS \\
\hline \multicolumn{2}{|l|}{$\mathrm{C} \times \mathrm{P}$} & & & NS & NS & NS & NS \\
\hline \multicolumn{2}{|c|}{$\mathrm{T} \times \mathrm{C} \times \mathrm{P}$} & & & NS & NS & NS & NS \\
\hline \multicolumn{2}{|l|}{ Year $(\mathrm{Y})$} & & & ${ }^{* * *}$ & $* * *$ & ${ }^{* * *}$ & $* * *$ \\
\hline \multicolumn{2}{|l|}{$\mathrm{T} \times \mathrm{Y}$} & & & NS & NS & NS & NS \\
\hline \multicolumn{2}{|l|}{$\mathrm{C} \times \mathrm{Y}$} & & & NS & NS & NS & NS \\
\hline \multicolumn{2}{|c|}{$\mathrm{T} \times \mathrm{C} \times \mathrm{Y}$} & & & NS & NS & NS & * \\
\hline \multicolumn{2}{|l|}{$\mathrm{P} \times \mathrm{Y}$} & & & NS & * & NS & NS \\
\hline \multicolumn{2}{|c|}{$\mathrm{T} \times \mathrm{P} \times \mathrm{Y}$} & & & NS & NS & NS & NS \\
\hline $\mathrm{C} \times \mathrm{P} \times$ & & & & NS & NS & NS & NS \\
\hline $\mathrm{T} \times \mathrm{C} \times \mathrm{I}$ & & & & NS & NS & $*$ & $*$ \\
\hline
\end{tabular}

${ }^{\mathrm{a}}$ Tillage practices are CT, conventional tillage; and NT, no-tillage; ${ }^{\mathrm{b}} \mathrm{See}$ Table 2 for the description of cultural practices; ${ }^{\mathrm{c}} \mathrm{Crop}$ rotations are $\mathrm{CW}$, continuous spring wheat; and W-B-C-P, spring wheat-barley hay-corn-pea.; ${ }^{\mathrm{d}}$ Numbers followed by different letters within a column in either year or crop rotation are significantly different at $P \leq 0.05$ by the least square means test; ${ }^{\mathrm{d}}$ Significance levels: ${ }^{*} P \leq 0.05 ;{ }^{* *} P \leq 0.01 ;{ }^{* * *} P \leq 0.001$; NS, Not significant. 
surface residue and soil $\mathrm{C}$ fractions but diversified crop rotation increased microbial biomass $\mathrm{C}$. The increases occurred at subsurface soil layers for non-labile $\mathrm{C}$ fractions but occurred at all layers for labile $\mathrm{C}$ fractions. However, the increases were short lived as $\mathrm{C}$ fractions declined rapidly compared to other treatments from autumn 2007 to spring 2008, probably a result of increased mineralization during the fallow period in the winter. This resulted in similar levels of soil $\mathrm{C}$ fractions among treatments in 2008. The ecological cultural practice did not increase surface residue and soil $\mathrm{C}$ fractions compared to the regular practice probably due to longer fallow period and continued $\mathrm{C}$ and $\mathrm{N}$ mineralization. For increasing dryland $\mathrm{C}$ storage and soil quality, no-tillage with diversified crop rotation and/or the regular cultural practice can be used compared to conventional tillage with monocropping and/or the ecological practice in the northern Great Plains, USA. For obtaining stable C levels and sequestration rates, however, long-term experiment than the present four years of study may be needed because of declining levels of surface residue and $\mathrm{C}$ fractions from autumn to spring. As a result, surface residue and soil samples would be preferable to collect at the same time (e.g. either after crop harvest in the autumn or before planting in the spring) of the year for determinations of $\mathrm{C}$ fractions under dryland cropping systems.

\section{Acknowledgements}

We sincerely acknowledge the help provided by Joy Barsotti, Chris Russell, and Johnny Rieger for collection and analysis of surface residue and soil samples in the field and laboratory and Michael Johnson and Mark Gaffri for management of field plots for tilling, planting, herbicide and pesticide application, and harvest.

\section{REFERENCES}

[1] R. Lal, J. M. Kimble and B. A. Stewart, "World Soils as a Source or Sink for Radiatively-Active Gases," In: R. Lal, Ed., Soil Management and Greenhouse Effect, Advances in Soil Science, CRC Press, Boca Raton, 1995, pp. 1-8.

[2] K. Paustian, G. P. Robertson and E. T. Elliott, "Management Impacts on Carbon Storage and Gas Fluxes in Mid-Latitudes Cropland," In: R. Lal, Ed., Soils and Global Climate Change, Advances in Soil Science, CRC Press, Boca Raton, USA, 1995, pp. 69-83.

[3] A. D. Halvorson, G. A. Peterson and C. A., Reule, "Tillage System and Crop Rotation Effects on Dryland Crop Yields and Soil Carbon in the Central Great Plains," Agronomy Journal, Vol. 94, No. 6, 2002, pp. 1429-1436. doi:10.2134/agronj2002.1429

[4] L. A. Sherrod, G. A. Peterson, D. G. Westfall and L. R. Ahuja, "Cropping Intensity Enhances Soil Organic Carbon and Nitrogen in a No-Till Agroecosystem," Soil Science Society of America Journal, Vol. 67, No. 5, 2003, pp.
1533-1543. doi:10.2136/sssaj2003.1533

[5] U. M. Sainju, T. Caesar-TonThat, A. W. Lenssen, R. G. Evans and R. Kolberg, "Long-Term Tillage and Cropping Sequence Effects on Dryland Residue and Soil Carbon Fractions," Soil Science Society of America Journal, Vol. 71, No. 6, 2007, pp. 1730-1739. doi: $10.2136 /$ sssaj2006.0433

[6] P. E. Rasmussen, R. R. Allmaras, C. R. Rhoade and N. C. Roager Jr., "Crop Residue Influences on Soil Carbon and Nitrogen in a Wheat-Fallow System," Soil Science Society of America Journal, Vol. 44, No. 3, 1980, pp. 596-600. doi:10.2136/sssaj1980.03615995004400030033x

[7] G. A. Peterson, A. D. Halvorson, J. L. Havlin, O. R. Jones, D. G. Lyon and D. L. Tanaka, "Reduced Tillage and Increasing Cropping Intensity in the Great Plains Conserve Soil Carbon," Soil and Tillage Research, Vol. 47, No. 3-4, 1998, pp. 207-218. doi:10.1016/S0167-1987(98)00107-X

[8] A. Bauer and A. L. Black, "Quantification of the Effect of Soil Organic Matter Content on Soil Productivity," Soil Science Society of America Journal, Vol. 58, No. 1, 1994, pp. 185-193.

doi:10.2136/sssaj1994.03615995005800010027x

[9] A. D. Halvorson, B. J. Wienhold and A. L. Black, "Tillage, Nitrogen, and Cropping System Effects on Soil Carbon Sequestration," Soil Science Society of America Journal, Vol. 66, No. 3, 2002, pp. 906-912. doi:10.2136/sssaj2002.0906

[10] T. O. West and W. M. Post, "Soil Organic Carbon Sequestration Rates by Tillage and Crop Rotation: A Global Data Analysis," Soil Science Society of America Journal, Vol. 66, No. 6, 2002, pp. 1930-1946. doi:10.2136/sssaj2002.1930

[11] A. W. Lenssen, G. D. Johnson and G. R. Carlson, “Cropping Sequence and Tillage System Influences Annual Crop Production and Water Use in Semiarid Montana," Field Crops Research, Vol. 100, No. 1, 2007, pp. 32-43. doi:10.1016/j.fcr.2006.05.004

[12] U. M. Sainju, A. W. Lenssen, T. Caesar-TonThat and R. G. Evans, "Dryland Crop Yields and Soil Organic Matter as Influenced by Long-Term Tillage and Cropping Sequence," Agronomy Journal, Vol. 101, No. 2, 2009, pp. 243-251. doi:10.2134/agronj2008.0080x

[13] M. F. Vigil, R. A. Anderson and W. E. Beard. "Base Temperature Growing-Degree-Hour Requirements for Emergence of Canola," Crop Science, Vol. 37, No. 3, 1997, pp. 844-849. doi:10.2135/cropsci1997.0011183X003700030025x

[14] P. R. Miller, B. McConkey, G. W. Clayton, S. A. Brandt, J. A. Staricka, A. M. Johnston, G. P. Lafond, B. G. Schatz, D. D. Baltensperger and K. E. Neill, "Pulse Crop Adaptation in the Northern Great Plains," Agronomy Journal, Vol. 94, No. 2, 2002, pp. 261-272. doi:10.2134/agronj2002.0261

[15] A. W. Lenssen, J. T. Waddell, G. D. Johnson and G. R. Carlson, "Diversified Cropping Systems in Semiarid Montana: Nitrogen Use during Drought," Soil and Tillage Research, Vol. 94, No. 2, 2007, pp. 362-375. doi:10.1016/j.still.2006.08.012 
[16] J. K. Aase and G. M Schaefer, "Economics of Tillage Practices and Spring Wheat and Barley Crop Sequence in the Northern Great Plains," Journal of Soil and Water Conservation, Vol. 51, No. 2, 1996, pp. 167-170.

[17] P. J. Gregory, J. S. I. Ingram, R. Anderson, R. A. Betts, V. Brovkin, T. N. Chase, P. R. Grace, A. J. Gray, N. Hamilton, T. B. Hardy, S. M. Howden, A. Jenkins, M. Meybeck, M., Olsson, I. Ortiz-Montasterio, C. A. Palm, T. W. Payn, M. Rummukainen, R. E. Schulze, M. Thiem, C. Valentin and M. J. Wikinson, "Environmental Consequences of Alternative Practices for Intensifying Crop Production," Agricultural Ecosystem and Environment, Vol. 88, No. 3, 2002, pp. 279-290. doi:10.1016/S0167-8809(01)00263-8

[18] A. J. Franzluebbers, F. M. Hons and D. A. Zuberer, "Soil Organic Carbon, Microbial Biomass, and Mineralizable Carbon and Nitrogen in Sorghum," Soil Science Society of America Journal, Vol. 59, No. 2, 1995, pp. 460-466. doi:10.2136/sssaj1995.03615995005900020027x

[19] D. F. Bezdicek, D. F. Papendick and R. Lal, "Introduction: Importance of Soil Quality to Health and Sustainable Land Management," In: J. W. Doran and A. J. Jones, Eds., Methods of Assessing Soil Quality, Spec. Publ. 49, Soil Science Society of America, Madison, 1996, pp. 1-18.

[20] P. G. Saffigna, D. S. Powlson, P. C. Brookes and G. A. Thomas, "Influence of Sorghum Residues and Tillage on Soil Organic Matter and Soil Microbial Biomass in an Australian Vertisol," Soil Biology and Biochemistry, Vol. 21, No. 6, 1989, pp. 759-765. doi:10.1016/0038-0717(89)90167-3

[21] E. Bremner and C. Van Kissel, "Plant-Available Nitrogen from Lentil and Wheat Residues during a Subsequent Growing Season," Soil Science Society of America Journal, Vol. 56, No. 4, 1992, pp. 1155-1160. doi:10.2136/sssaj1992.03615995005600040025x

[22] C. A. Cambardella and E. T. Elliott, "Particulate Soil Organic Matter Changes across a Grassland Cultivation Sequence," Soil Science Society of America Journal, Vol. 56, No. 3, 1992, pp. 777-783. doi:10.2136/sssaj1992.03615995005600030017x

[23] J. Six, E. T. Elliott and K. Paustian, "Aggregate and Soil Organic Matter Dynamics under Conventional and NoTillage Systems," Soil Science Society of America Journal, Vol. 63, No. 5, 1999, pp. 1350-1358. doi:10.2136/sssaj1999.6351350x

[24] H. J. Haas, W. O. Willis and J. J. Bond, "Summer Fallow in the Western United States," USDA Conservation Research Report Number 17, US Government Printing Office, Washington DC, 1974, pp. 2-35.

[25] R. A. Bowman, M. F. Vigil, D. C. Nielsen and R. L. Anderson, "Soil Organic Matter Changes in Intensively Cropped Dryland Systems," Soil Science Society of America Journal, Vol. 63, No. 1, 1999, pp. 186-191. doi:10.2136/sssaj1999.03615995006300010026x

[26] H. H. Schomberg and O. R. Jones, "Carbon and Nitrogen Conservation in Dryland Tillage and Cropping Systems," Soil Science Society of America Journal, Vol. 63, No. 5, 1999, pp. 1359-1366. doi:10.2136/sssaj1999.6351359x

[27] A. L. Black and D. L. Tanaka, "A Conservation Tillage Cropping System Study in the Northern Great Plains of the United States," In: E. A. Paul, Ed., Soil Organic Matter in Temperate Agroecosystems: Long-term Experiments in North America, CRC Press, Boca Raton, 1997, pp. 335-342.

[28] M. H. Entz, V. S. Baron, P. M. Carr, D. W. Meyer, S. R. Smith Jr. and W. P. McCaughey, "Potential of Forages to Diversity Cropping Systems in the Northern Great Plains," Agronomy Journal, Vol. 94, No. 2, 2002, pp. 240-250. doi:10.2134/agronj2002.0240

[29] S. M. Strydhorst, J. R. King, K. H. Lopetinsky and K. N. Harker, "Weed Interference, Pulse Species, and Plant Density Effects on Rotational Benefits," Weed Science, Vol. 56, No. 2, 2008, pp. 249-258. doi:10.1614/WS-07-118.1

[30] Eastern Agricultural Research Center, "Agricultural Research Update," Regional Rep. 2, Eastern Agricultural Research Center, Montana State University, Sidney, 1997.

[31] D. W. Nelson and L. E. Sommers, "Total Carbon, Organic Carbon, and Organic Matter,” In: D. L. Sparks, Ed., Methods of Soil Analysis, Part 3, Chemical Method, SSSA Book Ser. 5, Soil Science Society of America, Madison, 1996, pp. 961-1010.

[32] R. L. Haney, A. J. Franzluebbers, E. B. Porter, F. M. Hons and D. A. Zuberer, "Soil Carbon and Nitrogen Mineralization: Influence of Drying Temperature," Soil Science Society of America Journal, Vol. 68, No. 2, 2004, pp. 489-492. doi:10.2136/sssaj2004.0489

[33] J. L. Pikul Jr. and J.K. Aase, J. K., "Water infiltration and Storage Affected by Subsoiling and Subsequent Tillage," Soil Science Society of America Journal, Vol. 67, No. 3, 2003, pp. 859-866. doi:10.2136/sssaj2003.0859

[34] A. J. Franzluebbers, R. L. Haney, F. M. Hons and D. A. Zuberer, "Determination of Microbial Biomass and Nitrogen Mineralization Following Rewetting of Dried Soil," Soil Science Society of America Journal, Vol. 60, No. 4, 1996, pp. 1133-1139. doi:10.2136/sssaj1996.03615995006000040025x

[35] R. P. Voroney and E. A. Paul, "Determination of $k_{C}$ and $\mathrm{k}_{\mathrm{N}}$ in situ for Calibration of the Chloroform Fumigation-Incubation Method," Soil Biology and Biochemistry, Vol. 16, No. 1, 1984, pp. 9-14. doi:10.1016/0038-0717(84)90117-2

[36] R. C. Littell, G. A. Milliken, W. W. Stroup and R. R. Wolfinger, "SAS System for Mixed Models," SAS Institute Inc., Cary, 1996.

[37] U. M. Sainju, A. W. Lenssen, T. Caesar-TonThat and J. T. Waddell, "Tillage and Crop Rotation Effects on Dryland Soil and Residue Carbon and Nitrogen," Soil Science Society of America Journal, Vol. 70, No. 2, 2006, pp. 668678. doi:10.2136/sssaj2005.0089

[38] D. W. Fryrear, "Soil Cover and Wind Erosion," Transaction American Society of Agricultural Engineers, Vol. 28, No. 3, 1985, pp. 781-784.

[39] R. A. Ortega, G. A. Peterson and D. G. Westfall, "Residue Accumulation and Changes in Soil Organic Matter As Affected by Cropping Intensity in No-Till Dryland Agroecosystems," Agronomy Journal, Vol. 94, No. 4, 2002, pp. 944-954. doi:10.2134/agronj2002.0944 
[40] U.M. Sainju, A. W. Lenssen, T. Caesar-TonThat and J. T. Waddell, "Dryland Plant Biomass and Soil Carbon and Nitrogen Fractions on Transient Land as Influenced by
Tillage and Crop Rotation," Soil and Tillage Research, Vol. 93, No. 2, 2007, pp. 452-461.

doi:10.1016/j.still.2006.06.003 